\title{
TRASH TO TREASURE: INTEGRATING ENVIRONMENTAL AWARENESS INTO UNIVERSITY CURRICULUM
}

\author{
Polina Vasileva, Vadim Golubev, Ildar Ibragimov, Svetlana Rubtsova
}

St Petersburg University, Russia

\begin{abstract}
Over the last decade, educators around the world have paid increasing attention to raising public awareness of the need to make concerted efforts to provide a sustainable future for this planet. Many scientists and eco-activists have done a lot to develop public environmental consciousness using different educational tools. This paper discusses integrating environmental awareness into academic curriculum. It analyses the introduction of an environmental component to the English for the Media course offered at St Petersburg University. The experimental study was conducted for three semesters: in the spring semester of 2019 (February - May 2019), the fall semester of the same year (September - December 2019) and the spring semester of 2020 (February - May 2020). It involved 65 first - and second-year journalism students. Media professionals are responsible for changing the way people look at the environment. Project-based learning helps students to expand their environmental repertoires such as shaping public perception of 'green consumerism' as a fashionable trend. The growing awareness of environmental issues requires shaping consumer's mindfulness about obliteration and depletion of natural resources through irresponsible activities. The trash-to-treasure and eco-comics projects are lightweight, exciting and effective tools of raising environmental awareness in future media practitioners and enhancing their scientific writing skills. Using these skills journalists can make their environmental messages accessible to a broader public.
\end{abstract}

Key words: project method, ESP, environmental education, multi-disciplinary approach, eco-comics, critical thinking

\section{INTRODUCTION}

The environmental challenges of humanity caused by climate change and the fast rate of industrialization require implementing transformative strategies for establishing green, resource-efficient and low carbon communities.

In 2015, the UN drafted the resolution on sustainable development "Transforming our world: The agenda 2030 for Sustainable Development". The paper established 17 sustainable development goals including 169 associated targets which are drafted for stimulating initiative, monitoring performance and levering compliance.

Goal 13, which is called "Take urgent actions to combat climate change and its impacts," sets the following objectives: "Improve education, awareness-raising and human

Submitted December $13^{\text {th }}, 2020$, accepted for publication February $16^{\text {th }}, 2021$

Corresponding author: Polina Vasileva. St Petersburg University, Russia|E-mail: p.vasilyeva@spbu.ru 
and institutional capacity on climate change mitigation, adaptation, impact reduction and early warning" (UN 2015, p.23).

In this regard, one of the most powerful tools for increasing global environmental consciousness is to adjust environmental policy based on environmental education.

Increasingly, universities are encouraged to contribute to the sustainability of the planet. Thus, St Petersburg University ( $\mathrm{SPbU}$ ) in Russia launched its first Green Campus sustainability initiatives in 2015. Based on sustainable development principles, the university's environmental strategy includes research and academic activities aimed to raise environmental awareness in students and academic staff.

The main principles of the University's environmental policy include the following:

- the system approach to developing educational courses, carrying out research, fulfilling current and long-term objectives of the University;

- implementation of interdisciplinary and international projects aimed at studying the relationships within the "nature-society-man" system (SPbU, 2015).

It is stating the obvious that the University authorities are concentrated on creating new training interdisciplinary courses and integrating them into university curriculum to prepare future generations for a green society. In our previous publication, we examined the relationship between public awareness, attitude and environmental behavior of journalism students through eco-comics (Vasileva, Golubev, 2019). In the current paper we focus on implementing the project method as an effective educational medium for integrating environmental consciousness projects into academic curriculum. Eco-comics as well as the project method are examples of inquiry-based approaches enhancing future journalist scientific environmental knowledge and professional writing skills.

In our experimental study we implemented the trash-to-treasure project work concerning students' environmental behavior and consumption pattern, willingness and readiness to accept new sustainable fashion trends and green consumerism. The trash-to-treasure project in English is tightly connected with artistic skills development as it promotes students' creativity with recyclables. It can be regarded as a powerful instrument to boost the idea of zero waste consumerism and students' personal contribution to it on a global scale.

\section{The Project Methodas a Progressive Educational Paradigm}

The project method is often defined as a symbol of progressive education in the European and American pedagogical literature. The name of the American scholar William H. Kilpatrick has known worldwide as "Mr. Project Method" after publishing his famous essay "The Project Method" in 1918. Kilpatrick's ideas were based on the authentic comprehensive and coherent educational theory of J. Dewey who promoted a child-centered approach in education. In fact, the project method has rather long and fascinated history grown out of the architectural and engineering education movement that began in Italy during the late $16^{\text {th }}$ century. Later in the 1970s, the idea of the project method was rediscovered and received its third wave of its international dissemination as Michael Knoll marked (Knoll, 1997).

It is noteworthy that project method as a teaching tool has evolved from the pragmatism philosophy based on the principle that the usefulness, workability and practicality of ideas, policies and offers are the criteria of their merit.

We can find a great variety of teaching approaches, strategies, methods and even theories of cognitive structures based on the fundamental ideas of the progressive 
educational movement of the early $20^{\text {th }}$ century. For example, the concept of the constructivism theory is distinguished as "an approach to learning that holds that people actively construct or make their own knowledge and that reality is determined by the experiences of the learner" (Elliot, 2000).

In the 1970s the outstanding Soviet educator Lev Vygotsky developed his psychological theory on sociable constructivism. According to the theory, learning is a collaborative process and knowledge develops from individuals' interactions with their culture and society (Vygotsky, 1978).

According to our strong belief, such teaching approaches as inquiry-based learning and project-based learning, case-study and problem-solving methods, discovery or expeditionary learning can be regarded as derived notions of the original term "project method" with almost identical meaning. W. Kilpatrick defined the concept as "whole hearted purposeful activities" focused on acquiring practical skills and putting them into practice. Thus, the key target of any project task is to move learners towards getting some practical skills needed to be performed. Project method practitioners promote the idea of implementing learning through acting and experiencing.

Having reviewed on the project methodology, we can determine five distinguishing characteristics of the project method:

- learner-centered and content-based learning focused on providing problem-solving teaching strategy;

- encourage acquiring practical knowledge and its natural integration of skills;

- mastering the ability to group-work, cooperation and responsibility for one's own work;

- motivational benefits and developing critical thinking skills and ability to look for nonstandard solutions;

- require teachers and students to assume new roles and responsibilities; teachers serve as resources, facilitators and guides along the learning process.

- Summarizing the value of using project method in the classroom, we can distinguish the following drawbacks:

- it is only supplementary educational approach, not all subjects and whole subject content can be taught by it;

- it does not provide clear instructions for teachers how to plan and execute projects within the frame of academic curriculum.

In our experimental study we took into consideration the highlighted disadvantages. But we tried to give freedom to our students to create something new that could be really powerful and influential to follow the ideas of green consumerism through the trash-totreasure project work. We provide the review of the students' projects in the next section.

\subsection{Using the project method in the ESP classroom}

Various educational fields have successfully used project-based learning as an effective educational tool to foster learner's motivation and new knowledge acquisition related to the real world. There are a number of scientific papers covering the issues of the project method application at the level of pre-school, early-school and secondary school education.

Educators have highlighted numerous benefits and assumptions of using the project-based learning approach in applying it for teaching foreign languages. Firstly, it assumes a shift from teacher-centered memorization to student-centered investigation. Thus, it provides 
development of learner's ability to cooperate and enhancement of students' critical thinking and writing skills. Students are engaged in dealing with real-world tasks and materials.

Secondly, the key value of the project method concept is to give freedom from the traditional teaching approach which motivates students to learn through acting and experience as well as problem-solving activities.

Currently, project work is a crucial element for academic curriculum of tertiary education, as it provides interdisciplinary link between language acquisition and professional skills whatever field it can apply for. Particularly, it promotes developing professional journalist writing skills. As some researchers stress (Bolsunovskay, 2015) the main strength of the method is that students immediately turn to the specialty no matter which year of study they are in.

The other Russian scholar E.S. Polat (Polat, 2001) distinguished five main types of project work, in terms of dominating activity, relevant to teaching foreign languages: research, informative, creative, role-playing, practice-oriented. All the determined project types are applicable in the ESP classroom.

As we have previously noted, the project method fosters students' ability of collaboration and team work performing various functions: duty-holder, initiator, expert and researcher.

Last but not least, being involved in team work students make their own contribution to a shared work that motivates them for further development of their professional toolbox. This advantage of implementing projects in academic curriculum was highlighted by the British educator D.L. Fried-Booth in his publication covering the issue of project work (Fried-Booth, 2002).

\section{RESULTS}

\subsection{Discussion of experimental study}

We have been tackling the issue of shaping environmental consciousness of students by interactive teaching methods in the English classroom since February 2019. The experimental study was conducted during the following three semesters: in the spring semester of 2019 (February - May 2019), the fall semester of the same year (September December 2019) and the spring semester of 2020 (February - May 2020). It involved 65 first- and second-year journalism students.

During the first stage (February 2019 -May 2019) we ran an experimental project at the School of Journalism and Mass Communications of St. Petersburg University in public environmental awareness through eco-comics. The experimental study involved 38 firstyear students. The second stage was in the fall semester of the same year (September December 2019) and it was held in 2 groups involving 27 first-year students of journalism. In both cases the key target of the project was to motivate and inspire students to create their own eco-comics covering a diverse range of the environmental issues. Our research hypothesis was that eco-comics could be used as an effective educational tool for developing environmental awareness in students of journalism. While it seemed to be working in the classroom, we received devastating results at the evaluating stage of the experimental teaching. Three weeks after presenting their eco-comics projects the students were asked to do a questionnaire that consisted of seventeen factual questions about climate change. The purpose of the survey was to identify the respondents' awareness of climate change and reveal their perception of global warming. Unfortunately, about $30 \%$ of the 
respondents did not find the issue of climate change personally important to them even after having learned of its serious implications for the planet.

Nevertheless, getting a negative result of using eco-comics in the ESP classroom inspired us to continue our project-based teaching. During the spring semester of 2020 (February May 2020) we asked the students to complete a new project entitled Trash to Treasure. The target was to shape ecological consciousness of students of journalism via developing their recycling skills. We decided to change our teaching strategy a little and appealed more to the students' experience with sustainable (eco) fashion and green consumption trends.

The trash-to-treasure project consisted of four stages: the introductory stage, the analytical stage, the activity-oriented stage, and the evaluating stage.

Initially, taking into consideration our previous rather negative experience of shaping environmental consciousness of students via comics we did not ask students to study voluminous materials from English textbooks or to read numerous texts from the media related to environmental issues paying particular attention to thematic vocabulary prior to their project work as we had done in the eco-comics project. Instead, at the introductory stage the students were offered to watch several exciting short YouTube videos presenting the trash-totreasure conceptas a creative way of giving old things a new life. The students were easily hooked by the idea. It was a good beginning for further constructive discussion about the consequences of climate change and how they could contribute to climate change mitigation on a daily basis by conducting a zero waste lifestyle. Then they were offered to read some blogs promoting the zero waste concept as a real attempt to reduce one's carbon footprint in the world. Through reading, discussion and translation the students learned environmental vocabulary.

As we pointed out in our early paper (Vasileva, Golubev, 2019) environmental vocabulary contains many special terms which meanings are not always clear to the students (e.g. carbon dioxide emissions, greenhouse gases, energy efficient, industrial waste, toxic fumes, wastewater treatment, recycling, upcycling, low carbon, fossil fuels, urban sprawl, carbon footprint, illegal dumping, manmade disasters, landfills, sustainable fashion and sustainable development). Building up mind maps for better memorizing new words is one of the most effective approaches which we often apply in our teaching practice. Another method to boost students' memory capacity is creating association links. A student proposed a fascinated scheme explaining the zero waste concept stressing the connection of "4R rule" (Fig.1). It can be used as a training hand-out.

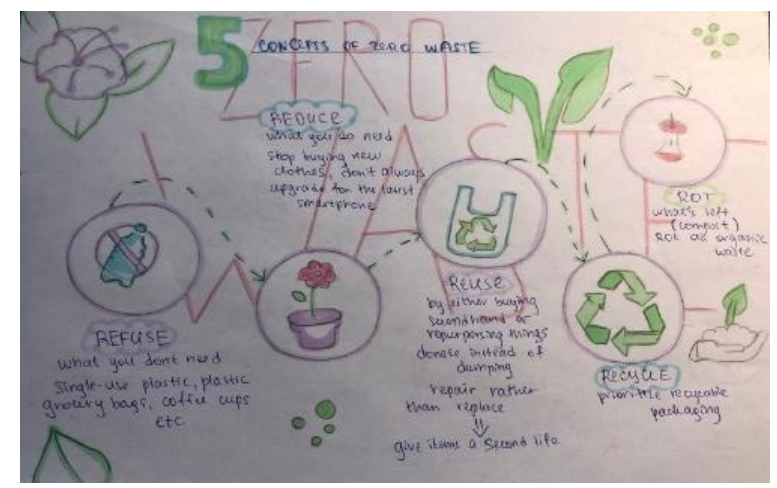

Fig.1 Zero waste concept 
Due to the Covid-19 lockdown, students were taught online in the spring semester of 2020 (February - May 2020). It required effective training methods that would help the students learn new vocabulary on the topic. The game-based learning platform Kahoot we used for this purpose allowed us to create, share and play learning games. This platform was originally created to teach English as well as other subjects to children. However, its competitive spirit made it a good tool for the ESP classroom. The students were given the task to build a vocabulary list in the form of a Kahoot quiz game. This approach is known as edutainment. A number of researchers and educational theorists have adopted the principles of edutainment learning in the university teaching practice (Zorica, 2014; Vasileva, 2017).

The analytical stage of the experiment was concentrated on reading texts, watching YouTube videos and discussing ecological and social issues that have been caused by the rapid development of fast fashion over the last two decades. The students studied materials on the concept of sustainable and ethical fashion. Some of them prepared short presentations about the devastating consequences of fast fashion. In their presentations they pointed out such problems as human rights violations, the rate of consumption, chemical pollution, water and textile waste. Some students made posters against the global mass market (Fig. 2) revealing the real cost of cheap garments produced by H\&M, Zara, BeFree etc.

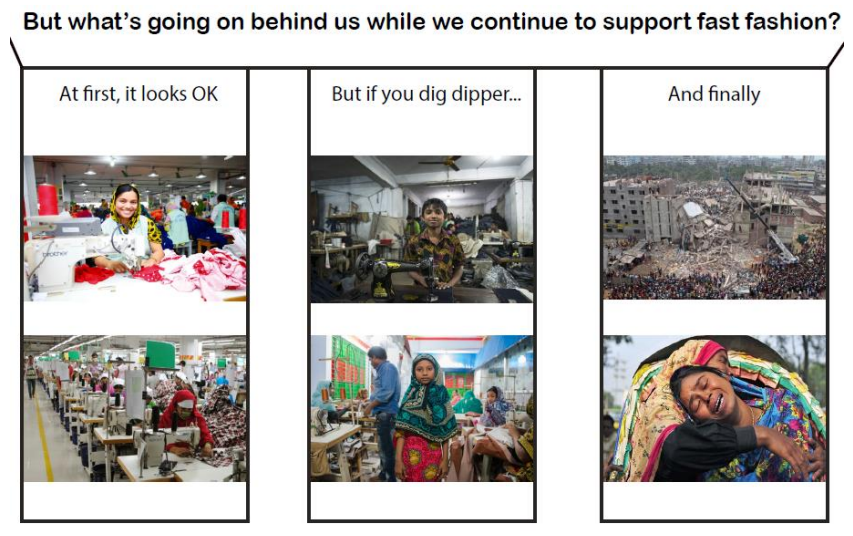

Fig.2 Mass market and human rights violations

At the third stage the students presented their project work that demonstrated their commitment to sustainable future. They were not limited in the choice of issues to be covered and ways of shaping public environmental consciousness. Many students were highly inspired to do project work based on their personal experience. As a result, they created fascinating upcycling products. The fashion industry is notorious for its massive waste problem; the big business is frequently called out for being one of the largest polluters globally. It is a remarkable thing that the restrictions imposed by the pandemic have led to raising popularity of upcycling fashion. Some students shared their personal upcycling experience (Fig.3, Fig.4). They made new prints for old garments and trendy shoppers with authentic print from old-fashioned clothing items. 


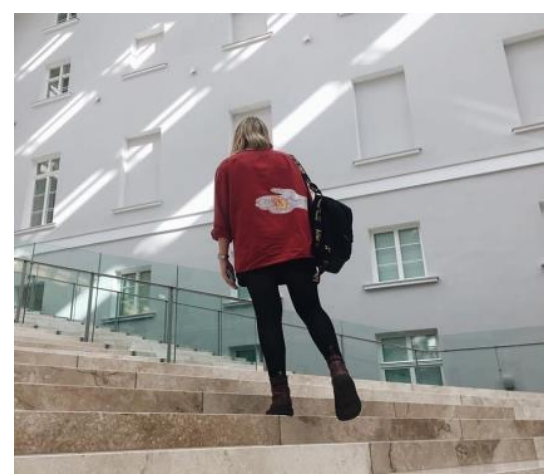

Fig.3 New print on old garment

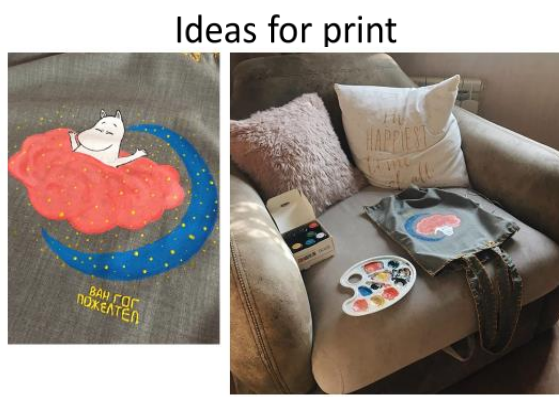

Fig. 4 Authentic print for a hand-made shopper

Most students devoted the projects to hand-made crafts or recyclables for decorating home interiors or countryside spaces. Vintage objects create atmospheric interior design (Fig.5, Fig.6). They seemed to be inspired by short YouTube videos watched at the first stage of our experimental study.

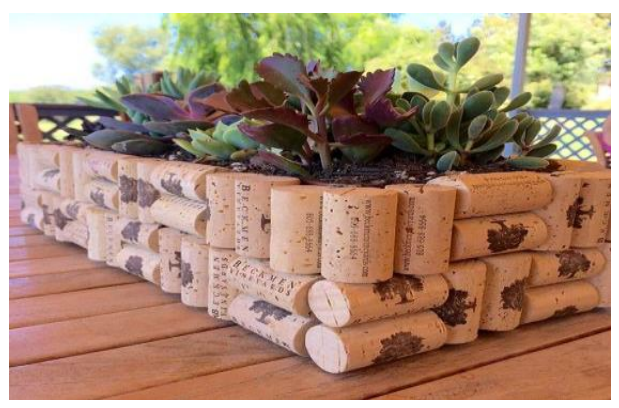

Fig. 5 Recyclable for decorating home interiors or countryside spaces 


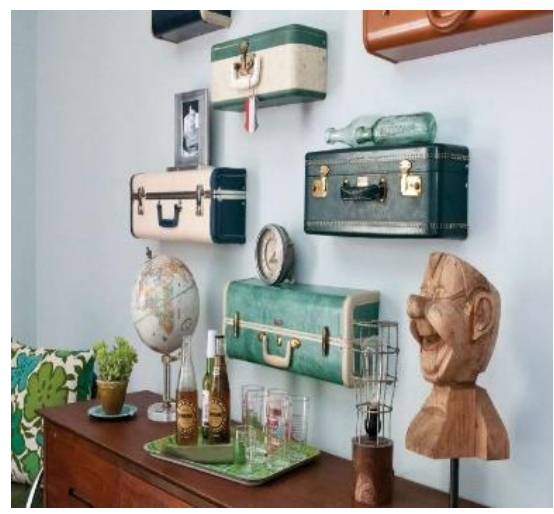

Fig. 6 Vintage-style recyclables

In the Russian pre-school and primary school, children often learn crafts to develop their practical skills. A student proposed a brilliant idea to create a puppet theatre with toilet paper tubes as one of the ways of promoting public environmental consciousness at an early stage of education (Fig.7).

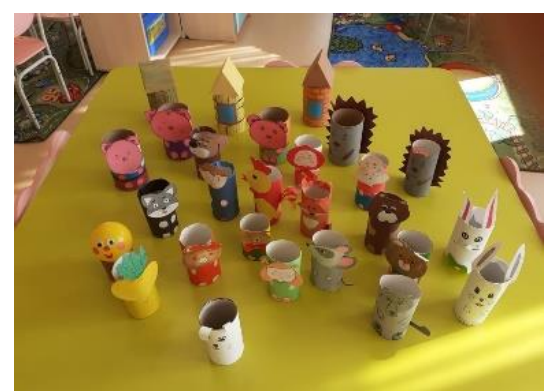

Fig. 7 Children's handicraft recyclables

We believe that the trash-to-treasure creative ideas were best implemented in the Russian countryside setting (Fig.8).

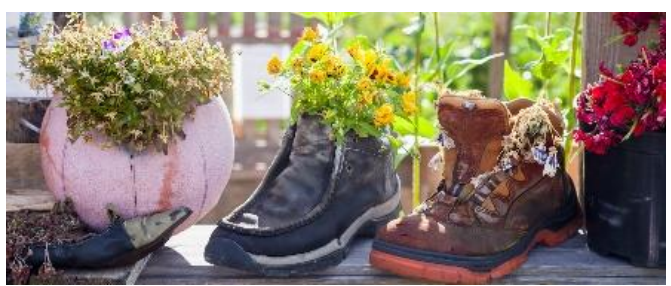

Fig. 8 Gardening recyclables

Overall, we can see that the project method is a powerful educational instrument for shaping the environmental consciousness of students. 


\subsection{Evaluating results}

Due to the pandemic lockdown the final - evaluating stage of the experimental work took place in October 2020. Almost a half a year later after doing the trash-to-treasure project work St Petersburg University students were asked to do a sustainable fashion survey, which consisted of a series of questions placed in an online Google form. In order to prove or disprove our research hypothesis whether the project method was an effective educational instrument for shaping the environment consciousness of students in the ESP classroom, we decided to involve not only the students of journalism who had participated in the trash-to-treasure project (the first group of respondents), but also students of journalism, mathematics and computer sciences who had not participated in the project (the second group of respondents). The first group consisted of 19, while the second of 201 students.

The purpose of the survey was to identify the respondents' environmental consciousness and their willingness to reduce their carbon footprint on a daily basis. The sustainable fashion survey consisted of 11 questions having subdivided into small groups of topics, but all of them appealed to green consumerism and clothes shopping habits. The questions focused on the concepts that had been discussed during the trash-to-treasure project. For example, we asked the respondents if they planned their shopping trips and wardrobe carefully or to what extent they agreed with the statement that wearing good clothes was part of leading the good life. The questionnaire included a group of questions revealing respondents' desire to learn about where the materials used in their products come from, what fashion brands did to minimize their impact on the environment or protect their workers' human rights, what issues were important to respondents that fashion brands tackled in order to reduce their long-term impacts on the world: global poverty, climate change, protection of the environment or gender inequality. Finally, the polled students indicated how supportive they were of sustainable fashion and what features best defined it. All the sustainable issues presented in the survey had been discussed in the classroom.

Some results of the survey could be said to have disproved our research hypothesis. As we can see from the pie charts (Fig. 9, 10) the first group of respondents plan their shopping trips and wardrobe more carefully than the second group. But more than $50 \%$ of respondents in both groups think that wearing good clothes is part of leading a good life. Thus, we can make a conclusion that the desire to look fashionable influences their consumer choices and both groups disagreed with the statement that fashion in clothes is just a way to get more money from the consumer.

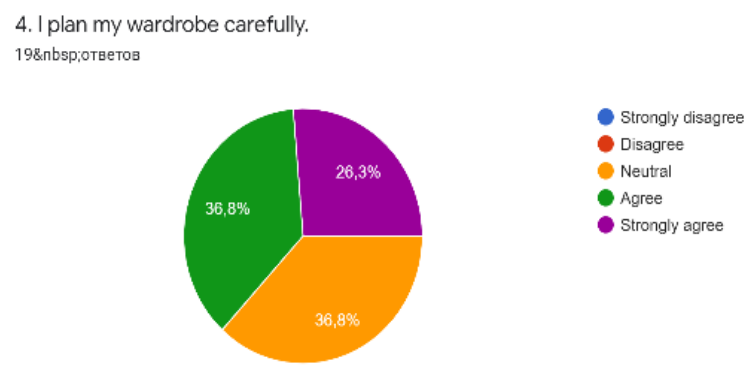

Fig.9 Students' attitude to planning wardrobe (group 1) 


\section{I plan my wardrobe carefully. \\ 201\&nbsp;ответ}

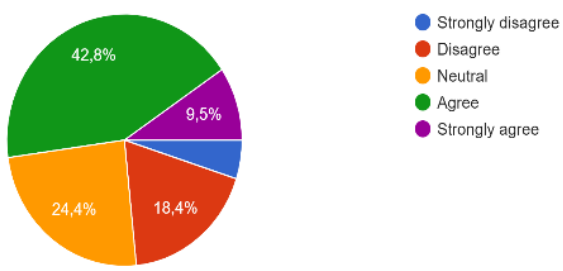

Fig.10 Students' attitude to planning wardrobe (group 2)

In terms of the respondents' interest in learning about social issues (human rights violations) and the efforts fashion brands made to minimize the environmental impact, the first group revealed a higher percentage of strong agree answers (Fig.11, 12) while the second group did not show much inspiration. We believe that this could be explained by the impact of the project-based teaching and the students' active social position as many of the first group respondents were females who supported feminist ideas. There is no wonder either why a half of the first group respondents stressed the importance of global poverty, which the fashion industry must address.

6. To what extent you agree or disagree with the following statement: I am interested in learning about what fashion brands do to protect their workers' human rights. 198пьвр;ответов

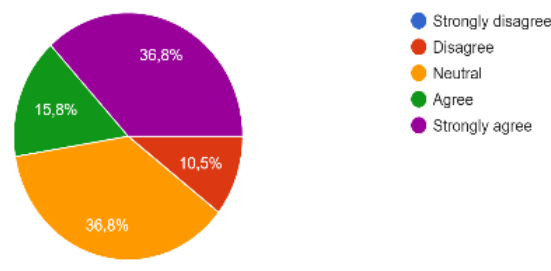

Fig.11 Students' attitude to human rights violations (group 1)

6. To what extent you agree or disagree with the following statement: I am interested in learning about what fashion brands do to protect their workers' human rights. 2018nbsp;oтвет

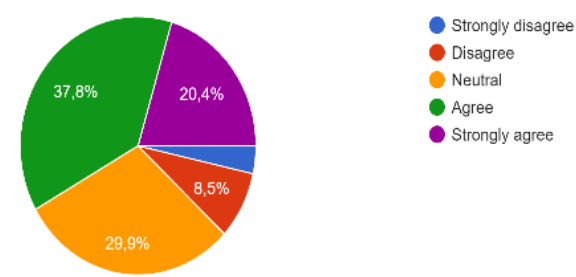

Fig.12 Students' attitude to human rights violations (group 2) 
To our great surprise we did not find much difference in the respondents' perception of sustainable fashion between the groups. Almost half of the respondents indicated support for sustainable fashion (58\% in group 1 and $45 \%$ in group 2).

\section{CONCLUSIONS}

Developing environmental awareness in students is crucial if we want hand over this planet to future generations. The project method lends itself well to developing students both English skills and environmental consciousness. Through speaking, listening, writing and, more importantly, creating their own artwork in English journalism students learned English environmental vocabulary and developed their professional skills as environmental educators who promoted a low carbon footprint lifestyle and green consumerism.

The most promising result of the Trash to Treasure study is that the respondents from group 1 revealed a higher percentage of environmental consciousness and personal interest to green consumerism. For example, about $47,7 \%$ of polled students from group 1 marked the importance of using recycled packaging whereas it is only $31 \%$ in group 2 . They also determined harmless environmental production as the key factor of their consumer choice. Unfortunately, the respondents of both groups did not point out the importance of developing locally produced fashion brands. Nevertheless, it makes us optimistic about the integration of the trash-to-treasure project work into academic curriculum.

We feel optimistic that the project will contribute the educational mission of journalism to provide the public with quality information about various matters including the environment and social injustice.

\section{REFERENCES}

Bolsunovskaya, L.M., Phillips, C., Korotchenko, T.V., Matveenko, I.A., Strelnikova, A.B., Ulyanova, O.S. (July, 2015). Project-based Method in Teaching Foreign Language for Specific Purposes. Paper presented at International Conference for International Education and Cross-cultural Communication. Problems and Solutions (IECC-2015), Tomsk Polytechnic University, Tomsk, Russia, p. 176-180.

Elliott, S.N., Kratochwill, T.R., Littlefield Cook, J. \& Travers, J. (2000). Educational psychology: Effective teaching, effective learning (3rd ed.). Boston, MA: McGraw-Hill College.

Fried-Booth, D.L. (2002). Project work. Oxford: Oxford University Press.

Knoll, M., (1997). The Project Method: Its Vocational Education Origin and International Development. Journal of Industrial Teacher Education, v34, n3, p59-80.

Polat, E.S. (2001). Metod proektov na urokakh inostrannogo yazyka. Foreign Languages in School, 1, 20-22. [Project-Based Method at English Lessons]. (Rus.)

SaintPetersburg University (2015) Green Campus. https://english.spbu.ru/our-university/ green-campus/ Accessed 05 December 2020.

Vasileva, P.A. (2017). Primenenie tekhnologii edutainment dlya razvitiya navykov ustnoy inoyazichnoy rechi studentov tekhnicheskogo vuza. Proceedings of the I International Methodological Training Conference "Innovative ideas and approaches to integrated teaching of foreign languages and professional-oriented subjects in high education" (March, 2017), St. Petersburg, Russia, p.204-206 [The Usage of Edutainment 
Technology in the Foreign Language Speech Development of Students of Technical University]. (Rus.)

Vasileva P., Golubev V. (2019). Eco-comics as an educational tool for teaching environmental journalism and ESP. Journal of Teaching English for Specific and Academic Purposes. 2019. Volume 7, № 4, p.431-442, http://espeap.junis.ni.ac.rs/index. php/espeap/issue/view/23. Accessed 05 December 2020.

Vygotsky, L. S. (1978). Mind in society: The development of higher psychological processes. (M. Cole, V. John-Steiner, S. Scribner, \& E. Souberman, Eds.). Cambridge, Massachusetts: Harvard University Press.

UN (2015) Transforming our world: the 2030 Agenda for Sustainable Development. Resolution adopted by the General Assembly on 25 September 2015. http://www.un.org/ es/comun/docs/index.asp?symbol=A/RES/70/1\&referer=/spanish/\&Lang=E. Accessed 05 December 2020.

Zorica, M. B. (2014). Edutainment at the Higher Education as an Element for the Learning Success. Proceedings of EDULEARN 14 Conference (July, 2014), Barcelona, Spain, p. 4089-4095. 